\title{
RESEARCH TO IDENTIFY EFFECTIVE
} ANITFUNGAL AGENTS

Annual Report

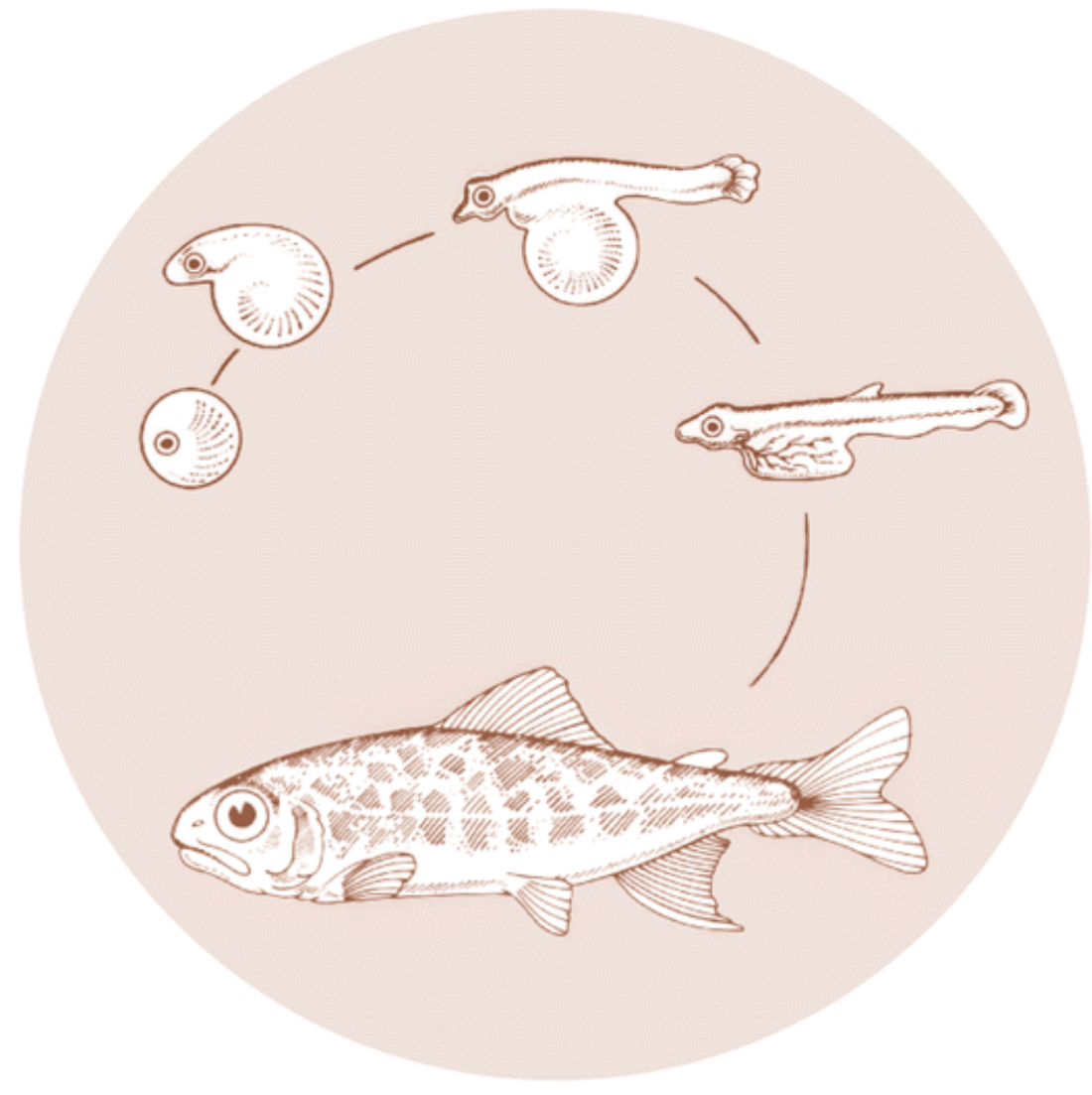

DOE/BP-02737-1 
This report was funded by the Bonneville Power Administration (BPA), U.S. Department of Energy, as part of BPA's program to protect, mitigate, and enhance fish and wildlife affected by the development and operation of hydroelectric facilities on the Columbia River and its tributaries. The views of this report are the author's and do not necessarily represent the views of BPA.

This document should be cited as follows:

Schreck, Carl; M. Fitzpatrick, Oregon Cooperative Fishery Research Unit, Marking, Leif L., J. J. Rach, S. M. Jeffrey, National Fisheries Research Center, Research To Identify Effective Antifungal Agents, Annual Report, to Bonneville

Power Administration, Portland, OR, Contract 89-AI-02737, Project 89-054, 24 electronic pages (BPA Report DOE/BP-02737-1)

This report and other BPA Fish and Wildlife Publications are available on the Internet at:

\section{http://www.efw.bpa.gov/cgi-bin/efw/FW/publications.cgi}

For other information on electronic documents or other printed media, contact or write to:

Bonneville Power Administration

Environment, Fish and Wildlife Division

P.O. Box 3621

905 N.E. 11th Avenue

Portland, OR 97208-3621

Please include title, author, and DOE/BP number in the request. 


\title{
RESEARCH TO IDENTIFY EFFECTIVE ANTIFUNGAL AGENTS
}

\author{
Annual Report \\ Prepared by: \\ Carl Schreck \\ Martin Fitzpatrick \\ Oregon Cooperative Fishery Research Unit \\ Leif L. Marking \\ Jeffrey J. Rach \\ Susan M. Jeffrey \\ National Fisheries Research Center
}

Prepared for:

U.S. Department of Energy

Bonneville Power Administration

Environment, Fish and Wildlife

PO Box 3621

Portland, Oregon 97208

Project No. 89-054

Contract No. DE-AI79-89BP02737

July 1990 


\section{Abstract}

Malachite green is effective in control of fungus on fish and fish eggs, but due to suspected teratogenicity its use is limited to the treatment of nonfood fish under an Investigational New Animal Drug Application held by the U.S. Fish and Wildlife Service. The reregistration of malachite green for treatment of fungus on food fish is highly unlikely. Consequently, the search for safe and effective aquatic fungicides must continue. The objectives of this study involved the selection and evaluation of candidate antifungal compounds on cultured fungus (Saprolegniales), fungus-infected eggs of rainbow trout and chinook salmon, and finally on adult spring chinook salmon. Minimum effective concentrations in vivo and minimum safe concentrations were established in order to calculate safety indices. Safety indices and hatching success were then used to evaluate effectiveness of candidate antifungal compounds. The four compounds that demonstrated the greatest safety on eggs were A-73336 (>4), Diquat (>5), formalin (5), and Herbisan (>5). Candidates A-39909, dichlorophen, 8-quinolinol sulfate, and peptides lacked effectiveness for control of fungus or were toxic to the eggs at fungicidal concentrations. Potassium permanganate will be tested further to reassess its potential.

The adult rearing facility was constructed and tested. Test groups of adult spring chinook were established to evaluate the extent of fungal infections at the site and the prophylactic effects of malachite green and formalin as standards against which to compare candidate compounds. These tests are ongoing. 


\section{Introduction}

Aquatic fungi (Saprolegniales) are ubiquitous in natural water supplies of fish hatcheries often causing serious disease problems. Malachite green is effective in control of fungus on fish and fish eggs, but due to suspected teratogenicity (Meyer and Jorgenson 1984) its use is limited to the treatment of non-food fish (i.e., eggs or adult salmon held for spawning) under an Investigational New Animal Drug Application held by the U.S. Fish and Wildlife Service. The reregistration of malachite green for treatment of fungus on food fish is highly unlikely. Presently, there is one registered aquatic fungicide, formalin, but it is not completely effective in control of fungus on fish or their eggs. Consequently, the search for safe and effective aquatic fungicides must continue.

Bailey (1984) and Bailey and Jeffrey (1989) reported results of tests with over 200 compounds that were chosen for fungicidal activity. More than half were found to be unsuitable as aquatic fungicides in preliminary tests because of their lack of activity against fungi, toxicity to fish or their eggs, insolubility in water, or potential carcinogenicity. However, several of the better candidates showed potential for control of fungus on fish eggs and were chosen for further evaluation.

The objectives of the present contract study were to select and evaluate up to 10 candidate fungicides. Evaluations for Goal I involve laboratory studies on efficacy of candidate compounds on cultured Saprolegniales, and on eggs of rainbow trout and chinook salmon that were previously infected with the fungus. Candidates that are effective 
for control of fungus on eggs will be tested further on adult spring chinook salmon (Goal II).

The main objective this year for Goal II was to determine the degree of fungal infection in untreated, control fish to establish the extent of the problem. Secondly, we needed to evaluate the prophylactic effects of malachite green and formalin against which to judge subsequent testing of candidate compounds.

\section{Materials and Methods}

\section{Goal I. Eggs and Juveniles}

In Vitro Tests

Pure strains of aquatic fungi were obtained from the American Type Culture Collection (ATCC). Saprolegnia hypogyna (ATCC 28275) was used for both range finding and minimum inhibitory concentration tests. Test procedures used were those developed by Bailey (1983a,b). The method involves an in vitro screening technique modified from that of Golden and Oster (1947) and a minimum inhibitory concentration determination based on the percent inhibition of growth in diameter of colonies (Bailey and Jeffrey 1989).

Range finding--Standard petri dishes were filled with $20 \mathrm{~mL}$ of corn meal agar and inoculated with agar plugs augmented with fungi (5 $\mathrm{mm}$ in diameter). The fungi was allowed to incubate at $20^{\circ} \mathrm{C}$ for approximately 96 hours. Agar plugs were removed from the edge of the colonies with a \#1 cork borer. Stock solutions of chemicals were prepared to achieve final concentrations of 1,10 , and $100 \mathrm{mg} / \mathrm{L}$. The depressions of Coors porcelain spot plates were filled with three 
replicates of each of the candidate chemicals and the solvent, positive, and negative controls.

Agar plugs were then added to the depressions of the spot plates for exposures of 15 and 60 minutes. Agar plugs were removed from the spot plates, rinsed three times with sterile distilled water, and placed on tri-petri dishes containing $30 \mathrm{~mL}$ of corn meal agar. Cultures were incubated in continuous light inside an environmental control chamber maintained at $20^{\circ} \mathrm{C}\left(+2^{\circ} \mathrm{C}\right)$. The plates were examined for mycelial growth after 48, 96, and 168 hours of incubation.

Minimum inhibitor-v concentration--Inoculations, incubation, and stock solution preparation were as stated above. Agar plugs were removed from the edge of the fungal colonies as previously described and exposed in triplicate to five delineative concentrations between 0.1 and $1.0 \mathrm{mg} / \mathrm{L}, 1.0$ and $10.0 \mathrm{mg} / \mathrm{L}$, or 10.0 and $100.0 \mathrm{mg} / \mathrm{L}$, depending on the activity observed in the range-finding test.

The agar plugs were exposed to the test chemicals in triplicate for 15 and 60 minutes. They were rinsed with sterile distilled water and placed on standard petri dishes containing $10 \mathrm{~mL}$ of corn meal agar. Cultures were incubated in a lighted environmental control chamber at $20^{\circ} \mathrm{C}$ for 48 hours, and the colony diameters were measured with a vernier caliper.

In Vivo Tests

Green eggs from Trout Lodge (McMillin. Washington) were placed in Heath incubating trays (500 eggs per tray) with the use of a modified egg counting board. Characteristics of the well water used 
for incubation were a total hardness of $138 \mathrm{mg} / \mathrm{L}$ as $\mathrm{CaCO}_{3}$, alkalinity of $105 \mathrm{mg} / \mathrm{L}$ as $\mathrm{CaCO}_{3}, \mathrm{pH}$ of 8.0 , and temperature of $12^{\circ} \mathrm{C}$.

The eggs were confined within a 6-inch diameter acrylic ring that was 1-inch in height and attached with silicone to the screen of each incubator tray. Two trays were used as replicates for each treatment level. All trays (except the negative controls) were inoculated with S. ferax on hemp seeds suspended by a tea ball in each of the trays. We allowed the eggs to become fungused for approximately 7 days. The chemicals were delivered to the back of the egg hatching trays with the use of a peristaltic pump to achieve a specific desired concentration. Eggs were exposed to the fungicides for 15 or 60 minutes. Treatments were administered three times weekly for a period of 2 weeks. Mortality and fungal infection were assessed prior to the first treatment (pretreatment), after the last treatment (post-treatment), and after the eggs hatched (post-hatch). Infection rates (\% increase) were calculated by subtracting pretreatment infection rates from post-treatment rates. Total hatch was assessed by subtracting the pretreatment mortality from the total number hatched.

\section{Toxicity Testing}

Toxicity of the candidate fungicides was established in dip treatments with green and eyed eggs of rainbow trout. Twenty-five eggs were placed in $125-\mathrm{mL}$ glass jars containing polyurethane screen mesh bottoms that were suspended in $12.0+1.0^{\circ} \mathrm{C}$ well water. The green eggs were dipped three times a week for 2 weeks into a dilution

series (2.5-L jars) of each test chemical for 15 or 60 minutes and then 
returned to well water. Eyed eggs were treated in a similar manner except fewer dip treatments were done due to egg hatching.

The dilution series was generally based on a use pattern of $1 / 2 \mathrm{X}$, LX, 3X, and 5X. The IX concentration was the concentration we felt would be effective for control of fungus. Mortality observations were taken daily and at the end of the test and egg hatching success was recorded. Margins of safety for each chemical were established by dividing the toxic concentration by the effective concentration for respective exposure times.

\section{Goal II. Adults}

An adult holding system was constructed adjacent to the Oregon Cooperative Fishery Research Unit's Smith Farm Experimental Hatchery in Corvallis, Oregon. The system was tested by transporting 25 adult spring chinook from the Oregon Department of Fish and Wildlife's Dexter Holding Facility to our new holding system on 3 July 1990. The fish performed well and no mortalities were experienced.

On 10 July 1990, 75 adult spring chinook from Dexter Holding Facility were trucked to the new holding system. These fish were injected with antibiotic (erythromycin and oxolinic acid) the day of transport. On July 20, 1990, the fish were distributed in equal numbers $(\mathrm{n}=10)$ among six lo-foot diameter by 4 -foot deep tanks.

Treatment protocols for malachite green and formalin were established following consultation with state and federal pathologists and hatchery managers. The protocols selected were those currently used at Willamette Hatchery for formalin or recommended by state 
pathologists for malachite green because we wanted to simulate as closely as possible treatments used at production facilities.

This particular hatchery is most appropriate for our stock of fish. Treatment commenced on 22 July 1990 and consisted of treating fish with a bolus every other day of $0.5 \mathrm{ppm}$ Malachite green or 1:6000 formalin in the flow-through system. The flow rate was about $45 \mathrm{~L} / \mathrm{min}$ for each tank. Dye depletion studies with fluorescein and others with malachite green using fluorometry and spectrophotometry, respectively, indicated effective treatment levels of the chemicals would be 2-4 hours.

The study design was established after consultation with research pathologists and a statistician. All test groups, controls, malachite green and formalin, were duplicated. Mortality was followed through time of maturity in all experimental groups.

\section{Modifications in Test Procedures}

Several modifications in test procedures were instituted for subsequent experiments as a result of negotiations with BPA staff and some erratic test results. Toxicity tests in the future will he done in the egg incubators simultaneously with the efficacy exposures. Therefore, uninfected eggs from the same source will also be exposed to the selected efficacious concentration as well as at the $3 \mathrm{X}$ and $5 \mathrm{X}$ rates. To ensure better mixing of candidate toxicants in the incubation water, a single initial tray was devoted to mixing by installing baffles in the tray to disperse the toxicant. 


\section{Results and Discussion}

The infection rate of healthy rainbow trout eggs varied between groups of eggs and between eggs of the same group for different chemicals (Appendices 1-5). Initial infection rate for eggs in the first test (Appendix 1) was very low: however, the increase in fungal infection in the positive control was substantially higher at $43.7 \%$ than in the negative control at $18.2 \%$. Those eggs treated with A-73336 and Diquat showed good hatch percentages while those treated with 8-quinolinol sulfate showed poorer hatch. Since the initial infection rate was low on these tests, the compounds were tested again.

The initial infection rate was higher in subsequent tests (Appendices 2-5) in which we attempted to get an infection rate of about $10 \%$. In those exposures A-73336 at $5 \mathrm{mg} / \mathrm{L}$ demonstrated better hatch percentage than other candidates and also better than with malachite green. Eggs exposed to Diquat also showed greater hatch percentages. Herbisan 5 (Appendix 5) showed improved hatching percentages at $10 \mathrm{mg} / \mathrm{L}$ in 15-minutes exposures but less efficiency in the longer exposure and at higher concentrations. We noticed precipitation at higher concentrations: probably because the chemical was formulated in xylene. We plan to test another sample of technical grade Herbisan 5.

Minimum effective concentrations (MEC) and minimum safe concentrations (MSC) were estimated from exposure data (Appendix 7) and often provided only "greater than" information (Table 1). Therefore, some of the values are not precise, but they are useful in preliminary evaluations. The four compounds demonstrating the 
greatest safety are A-73336 (>4), Diquat (25). formalin (5). and Herbisan (25). Candidates A-39909, dichlorophen, 8-quinolinol sulfate, and peptides lack effectiveness for control of fungus or are toxic to the eggs at fungicidal concentrations. The latter candidates will not be considered further in the efforts to find an effective fungicide for use on fish and their eggs. Potassium permanganate will be tested further to reassess its potential.

The initial study of adults was completed on 11 September 1990. At that time, all animals in both control tanks had died, whereas $10 \%$ or less mortality was suffered in the groups treated with malachite green or formalin (Table II). Examination of all animals on 14 August 1990 (approximately 1 month after arrival at the site) revealed the incidence of fungal growth on the gills of control fish, but no occurrence of fungal growth on the gills of any treated fish. 


\section{Literature Cited}

Bailey, T. A. 1983a. Method for in vitro screening of aquatic fungicides. Journal of Fish Diseases 6:91- 100.

Bailey, T. A. 1983b. Screening fungicides for use in fish culture:

Evaluation of the agar plug transfer, cellophane transfer, and agar dilution methods. The Progressive Fish-Culturist 45:24-27.

Bailey, T. A. 1984. Effects of twenty-five compounds on four species of aquatic fungi (Saprolegniales) pathogenic to fish. Aquaculture 38:97-104.

Bailey, T. A. and S. M. Jeffrey. 1989. Evaluation of 215 candidate fungicides for use in fish culture. U.S. Fish and Wildlife Service, Investigations in Fish Control 99. 9 pp.

Golden, J. J., and K. A. Oster. 1947. Evaluation of a fungicidal laboratory test method. Journal of American Pharmaceutical Association 36:350-362.

Meyer, F. P., and T. A. Jorgenson. 1984. Teratological and other effects of malachite green on development in rabbits and rainbow trout. Transactions of the American Fisheries Society 112:8 18-824. 
Table 1. Effectiveness ( $\mathrm{mg} / \mathrm{L})$ of candidate fungicides on cultured fungus (Saprolegnia hypogyna) and on eyed eggs of rainbow trout infected with fungus in terms of MIC (minimum inhibitory concentration), MEC (minimum effective concentration). and MSC (minimum safe concentration).

\begin{tabular}{|c|c|c|c|c|c|c|}
\hline \multirow[b]{2}{*}{$\begin{array}{l}\text { Chemical } \\
\text { name }\end{array}$} & \multirow{2}{*}{$\begin{array}{l}\text { Exposure } \\
\text { time } \\
\text { (min) }\end{array}$} & \multicolumn{2}{|c|}{ In vitro } & \multirow{2}{*}{$\begin{array}{l}\text { In } \\
\text { vivo } \\
\text { MEC }\end{array}$} & \multirow{2}{*}{$\begin{array}{l}\text { Toxicity } \\
\text { (MSC) } \\
\text { eyed } \\
\text { eggs }\end{array}$} & \multirow{2}{*}{$\begin{array}{l}\text { Safety } \\
\text { index } \\
\text { eyed } \\
\text { eggs }\end{array}$} \\
\hline & & Range & MIC & & & \\
\hline A-39909 & $\begin{array}{l}15 \\
60\end{array}$ & $\begin{array}{l}>1<10 \\
>1<10\end{array}$ & $\begin{array}{l}\leq 1.0 \\
\leq 1.0\end{array}$ & $\begin{array}{l}>5.0 \\
>5.0\end{array}$ & $\begin{array}{l}5.0 \\
2.5\end{array}$ & $\begin{array}{l}<1 \\
>0.5\end{array}$ \\
\hline A-73336 & $\begin{array}{l}15 \\
60\end{array}$ & $\begin{array}{l}>1<10 \\
>1<10\end{array}$ & $\begin{array}{l}\leq 1.0 \\
\leq 1.0\end{array}$ & $\begin{array}{l}>5.0 \\
>5.0\end{array}$ & $\begin{array}{l}\geq 20 \\
\geq 20\end{array}$ & $\begin{array}{l}24 \\
24\end{array}$ \\
\hline Dichlorophen & $\begin{array}{l}15 \\
60\end{array}$ & $\begin{array}{l}>1<10 \\
>1<10\end{array}$ & $\begin{array}{l}<5.0 \\
<3.0\end{array}$ & $\begin{array}{l}>5.0 \\
>5.0\end{array}$ & $\begin{array}{l}210 \\
210\end{array}$ & $\begin{array}{l}2 \\
2\end{array}$ \\
\hline Diquat & $\begin{array}{l}15 \\
60\end{array}$ & $\begin{array}{l}>100 \\
>100\end{array}$ & $\begin{array}{l}<700 \\
<500\end{array}$ & $\begin{array}{l}100 \\
100\end{array}$ & $\begin{array}{l}\geq 500 \\
\geq 500\end{array}$ & $\begin{array}{l}25 \\
25\end{array}$ \\
\hline Formalin & $\begin{array}{l}15 \\
60\end{array}$ & $\begin{array}{l}>100 \\
>100\end{array}$ & $\begin{array}{l}<300 \\
<300\end{array}$ & $\begin{array}{l}1667 \\
1000\end{array}$ & $\begin{array}{l}5,000 \\
1,667\end{array}$ & $\begin{array}{l}3 \\
1.7\end{array}$ \\
\hline Herbisan & $\begin{array}{l}15 \\
60\end{array}$ & $\begin{array}{l}>100 \\
>100\end{array}$ & $\begin{array}{l}-- \\
--\end{array}$ & $\begin{array}{l}210 \\
\geq 10\end{array}$ & $\begin{array}{l}\geq 50 \\
\geq 50\end{array}$ & $\begin{array}{l}25 \\
\geq 5\end{array}$ \\
\hline $\mathrm{KMnO}_{4}$ & $\begin{array}{l}15 \\
60\end{array}$ & $\begin{array}{l}>100 \\
>100\end{array}$ & $\begin{array}{l}<500 \\
<250\end{array}$ & $\begin{array}{l}100 \\
100\end{array}$ & $\begin{array}{c}\geq 250 \\
150\end{array}$ & $\begin{array}{l}>2.5 \\
1.5\end{array}$ \\
\hline Malachite green & $\begin{array}{l}15 \\
60\end{array}$ & $\begin{array}{l}<1 \\
<1\end{array}$ & $\begin{array}{l}0.5 \\
0.5\end{array}$ & $\begin{array}{l}5.0 \\
5.0\end{array}$ & $\begin{array}{c}\geq 25 \\
15\end{array}$ & $\begin{array}{l}\geq 5 \\
3\end{array}$ \\
\hline Peptides & $\begin{array}{l}15 \\
60\end{array}$ & $\begin{array}{l}>100 \\
>100\end{array}$ & $\begin{array}{l}-- \\
--\end{array}$ & $\begin{array}{l}-- \\
--\end{array}$ & $\begin{array}{l}-- \\
--\end{array}$ & $\begin{array}{l}-- \\
--\end{array}$ \\
\hline 8-Quinolinol SO4 & $\begin{array}{r}15 \\
60\end{array}$ & $\begin{array}{l}>100 \\
>100\end{array}$ & $\begin{array}{l}\leq 100 \\
\leq 100\end{array}$ & $\begin{array}{l}>100 \\
>100\end{array}$ & $\begin{array}{c}\geq 250 \\
150\end{array}$ & $\begin{array}{l}<2.5 \\
<1.5\end{array}$ \\
\hline
\end{tabular}


Table II. Mortality, Maturation, and Incidence of Fungal Growth in Adult Spring Chinook salmon held in Corvallis, Oregon.

\begin{tabular}{lcccc}
\hline Treatment & $\mathrm{n}$ & \%mortality & \%maturity & \%fungal growth \\
\hline Control & 11 & 100 & 0 & $100(1)$ \\
Control & 10 & 100 & 0 & $33(6)$ \\
& & & & $0(10)$ \\
Malachite Green & 10 & 10 & 10 & $0(10)$ \\
Malachite Green & 10 & 10 & 50 & $0(10)$ \\
Formalin & 10 & 0 & 30 & $0(10)$ \\
Formalin & 10 & 0 & 40 & \\
\hline
\end{tabular}

Key: " $n$ " indicates the number of individuals at the beginning of the experiment; "\% mortality" indicates the percentage of " $n$ " that died as of 11 September 1990; "\% maturity" indicates the percentage of " $n$ " that reached sexual ripeness as of 20 September 1990; "\% fungal growth" indicates the percentage of surviving individuals (given in parentheses) with fungal growth on gills on 14 August 1990. 
Appendices 
Appendix 1. Effectiveness of candidate fungicides on infected eggs of rainbow trout.

\begin{tabular}{|c|c|c|c|c|c|}
\hline \multirow[b]{2}{*}{ Compound } & \multirow{2}{*}{$\begin{array}{c}\text { Concentration } \\
(\mathrm{mg} / \mathrm{L})\end{array}$} & \multirow{2}{*}{$\underset{(\min )}{\text { Exposure }}$} & \multicolumn{2}{|c|}{ infection (\%) } & \multirow{2}{*}{$\begin{array}{l}\text { Hatcha }^{\mathrm{a}} \\
(\%)\end{array}$} \\
\hline & & & Initial & Increase & \\
\hline (+) Control & -- & & 1.3 & 43.7 & 68.3 \\
\hline (-) Control & -- & & 0.0 & 18.2 & 85.8 \\
\hline A-73336 & 2.0 & 15 & 0.1 & 24.0 & 85.1 \\
\hline A-73336 & 2.0 & 60 & 1.0 & 12.2 & 89.2 \\
\hline A-73336 & 4.0 & 15 & 0.2 & 17.8 & 93.3 \\
\hline A-73336 & 4.0 & 60 & 1.0 & 7.9 & 88.8 \\
\hline 8-Quinolinol SO4 & 50.0 & 15 & 0.0 & 45.1 & 62.4 \\
\hline 8-Quinolinol SO4 & 50.0 & 60 & 2.3 & 39.4 & 68.6 \\
\hline Diquat & 50.0 & 15 & 1.3 & 32.8 & 85.2 \\
\hline Diquat & 50.0 & 60 & 3.6 & 25.0 & 87.9 \\
\hline Diquat & 100.0 & 15 & 0.7 & 31.8 & 83.4 \\
\hline Diquat & 100.0 & 60 & 1.9 & 24.1 & 75.0 \\
\hline
\end{tabular}

aHatch calculation: $\frac{\text { number hatched }}{\text { total }-}$ initial morts $\quad$ x 00 
Appendix 2. Effectiveness of candidate fungicides on infected eggs of rainbow trout.

\begin{tabular}{lccccc}
\hline \multicolumn{1}{c}{ Compound } & $\begin{array}{c}\text { Concentration } \\
(\mathrm{mg} / \mathrm{L})\end{array}$ & $\begin{array}{c}\text { Exposure } \\
(\mathrm{min})\end{array}$ & Initial & Increase & $\begin{array}{c}\text { Hatch } \\
(\%)\end{array}$ \\
\hline (+) Control & -- & -- & 9.8 & 53.9 & 30.6 \\
(-) Control & -- & -- & 1.9 & 70.6 & 27.7 \\
& & & & & \\
Malachite green & 5.0 & 15 & 9.0 & 27.4 & 68.6 \\
Malachite green & 5.0 & 60 & 10.9 & 26.7 & 80.8 \\
& & & & & \\
A-73336 & 5.0 & 15 & 9.8 & 14.9 & 85.0 \\
A-73336 & 5.0 & 60 & 10.9 & 6.7 & 88.1 \\
& & & & & \\
8-Quinolinol SO4 & 100.0 & 15 & 3.0 & 63.6 & 35.3 \\
8-Quinolinol SO4 & 100.0 & 60 & 14.8 & 51.5 & 28.1 \\
& & & & & \\
Dichlorophen & 2.0 & 15 & 10.4 & 48.4 & 47.8 \\
Dichlorophen & 2.0 & 60 & 1.4 & 45.5 & 58.0 \\
Dichlorophen & 5.0 & 15 & 6.6 & 35.0 & 62.6 \\
Dichlorophen & 5.0 & 60 & 5.9 & 45.6 & 70.1 \\
\hline
\end{tabular}

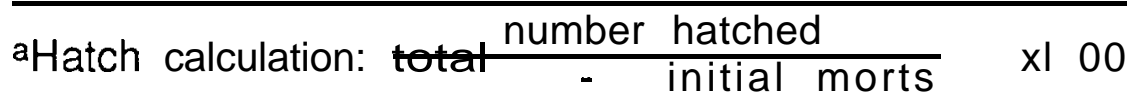


Appendix 3. Effectiveness of candidate fungicides on infected eggs of rainbow trout .

\begin{tabular}{|c|c|c|c|c|c|}
\hline \multirow[b]{2}{*}{ Compound } & \multirow{2}{*}{$\begin{array}{l}\text { Concentration } \\
(\mathrm{mg} / \mathrm{L})\end{array}$} & \multirow{2}{*}{$\begin{array}{c}\text { Exposure } \\
\text { (min) }\end{array}$} & \multicolumn{2}{|c|}{ Infection (\%) } & \multirow{2}{*}{$\begin{array}{l}\text { Hatche } \\
(\%)\end{array}$} \\
\hline & & & Initial & Increase & \\
\hline (+)Control & & & 17.4 & 43.5 & 34.6 \\
\hline ( - ) Control & & & 0.4 & 24.9 & 70.1 \\
\hline Malachite green & 5.0 & 15 & 5.2 & 33.1 & 56.6 \\
\hline Malachite green & 5.0 & 60 & 9.0 & 24.4 & 62.2 \\
\hline $\mathrm{KMnO}_{4}$ & 50.0 & 15 & 7.1 & 46.1 & 38.3 \\
\hline $\mathrm{KMnO}_{4}$ & 50.0 & 60 & 14.0 & 35.6 & 37.1 \\
\hline $\mathrm{KMnO}_{4}$ & 100.0 & 15 & 5.6 & 37.4 & 57.7 \\
\hline $\mathrm{KMnO}_{4}$ & 100.0 & 60 & 14.6 & 25.0 & 44.5 \\
\hline Formalin & 100.0 & 15 & 9.6 & 48.1 & 26.0 \\
\hline Formalin & 100.0 & 60 & 10.1 & 37.3 & 38.1 \\
\hline Formalin & 250.0 & 15 & 12.3 & 38.4 & 34.2 \\
\hline Formalin & 250.0 & 60 & 6.5 & 36.5 & 40.5 \\
\hline
\end{tabular}


Appendix 4. Effectiveness of candidate fungicides on infected eggs of rainbow trout.

\begin{tabular}{|c|c|c|c|c|c|}
\hline \multirow[b]{2}{*}{ Compound } & \multirow{2}{*}{$\begin{array}{l}\text { Concentration } \\
(\mathrm{mg} / \mathrm{L})\end{array}$} & \multirow{2}{*}{$\begin{array}{l}\text { Exposure } \\
\text { (min) }\end{array}$} & \multicolumn{2}{|c|}{ Infection (\%) } & \multirow{2}{*}{$\begin{array}{c}\text { Hatch } \\
(\%)\end{array}$} \\
\hline & & & Initial & Increase & \\
\hline (+) Control & & & 7.6 & 42.7 & 44.0 \\
\hline (-) Control & & & 1.5 & 36.4 & 62.8 \\
\hline A-39909 & 2.5 & 15 & 10.2 & 30.3 & 46.3 \\
\hline A-39909 & 2.5 & 60 & 5.7 & 31.4 & 53.9 \\
\hline A-39909 & 5.0 & 15 & 9.8 & 37.1 & 55.5 \\
\hline A-39909 & 5.0 & 60 & 6.5 & 70.0 & 19.2 \\
\hline Diquat & 50.0 & 15 & 14.9 & 33.8 & 66.1 \\
\hline Diquat & 50.0 & 60 & 7.2 & 40.2 & 59.2 \\
\hline Diquat & 100.0 & 15 & 8.0 & 23.8 & 71.9 \\
\hline Diquat & 100.0 & 60 & 8.5 & 26.9 & 68.2 \\
\hline Diquat & 200.0 & 15 & 11.8 & 41.8 & 52.5 \\
\hline Diquat & 200.0 & 60 & 7.5 & 32.0 & 71.1 \\
\hline
\end{tabular}


Appendix 5. Effectiveness of Herbisan 5 on infected eggs of rainbow trout.

\begin{tabular}{|c|c|c|c|c|c|}
\hline \multirow[b]{2}{*}{ Compound } & \multirow{2}{*}{$\begin{array}{l}\text { Concentration } \\
(\mathrm{mg} / \mathrm{L})\end{array}$} & \multirow{2}{*}{$\begin{array}{l}\text { Exposure } \\
\text { (min) }\end{array}$} & \multicolumn{2}{|c|}{ Infection (\%) } & \multirow{2}{*}{$\begin{array}{c}\text { Hatcho }^{\circ} \\
(\%)\end{array}$} \\
\hline & & & $\overline{\text { Initial }}$ & Increase & \\
\hline (+) Control & -- & & 13.9 & 31.5 & 58.3 \\
\hline (-) Control & -- & & 1.4 & 30.0 & 65.5 \\
\hline Herbisan 5 & 1.0 & 15 & 14.2 & 35.5 & 55.0 \\
\hline Herbisan 5 & 1.0 & 60 & 9.9 & 22.4 & 64.8 \\
\hline Herbisan 5 & 5.0 & 15 & 14.2 & 23.3 & 54.7 \\
\hline Herbisan 5 & 5.0 & 60 & 13.3 & 23.2 & 58.7 \\
\hline Herbisan 5 & 10.0 & 15 & 6.9 & 25.6 & 71.0 \\
\hline Herbisan 5 & 10.0 & 60 & 10.3 & 54.4 & 36.5 \\
\hline Herbisan 5 & 50.0 & 15 & 18.8 & 33.1 & 44.8 \\
\hline Herbisan 5 & 50.0 & 60 & 16.4 & 58.2 & 16.8 \\
\hline Herbisan 5 & 100.0 & 15 & 13.6 & 50.6 & 27.4 \\
\hline Herbisan 5 & 100.0 & 60 & 10.5 & 68.4 & 2.9 \\
\hline
\end{tabular}


Appendix 6. Effectiveness of Formalin on infected eggs of rainbow trout.

\begin{tabular}{|c|c|c|c|c|c|}
\hline \multirow[b]{2}{*}{ Compound } & \multirow{2}{*}{$\begin{array}{l}\text { Concentration } \\
\text { (mg/L) }\end{array}$} & \multirow{2}{*}{$\begin{array}{c}\text { Exposure } \\
\text { (min) }\end{array}$} & \multicolumn{2}{|c|}{ Infection (\%) } & \multirow{2}{*}{$\begin{array}{l}\text { Hatcha }^{\mathrm{a}} \\
(\%)\end{array}$} \\
\hline & & & Initial & $\overline{\text { Increase }}$ & \\
\hline (+) Control & -- & -- & 35.2 & 38.6 & 48.4 \\
\hline (-) Control & -- & -- & 14.9 & 60.0 & 54.7 \\
\hline Formalin & 1000 & 15 & 24.0 & 45.5 & 53.2 \\
\hline Formalin & 1000 & 60 & 10.8 & 29.5 & 62.3 \\
\hline Formalin & 1667 & 15 & 38.3 & 20.5 & 63.5 \\
\hline Formalin & 1667 & 60 & 10.5 & 0.5 & 77.0 \\
\hline Formalin & 2000 & 15 & 38.5 & 7.3 & 69.4 \\
\hline Formalin & 2000 & 60 & 38.5 & 10.7 & 74.9 \\
\hline
\end{tabular}


Appendix 7. Hatching success $(\%)^{\text {a }}$ of rainbow trout green and eyed eggs after dip treatments using candidate fungicide compounds.

\begin{tabular}{|c|c|c|c|c|c|c|c|c|}
\hline \multirow[b]{2}{*}{ Chemical } & \multirow[b]{2}{*}{$\begin{array}{l}\text { Egg } \\
\text { stage }\end{array}$} & \multirow{2}{*}{$\begin{array}{c}\text { Number } \\
\text { of } \\
\text { dips }\end{array}$} & \multirow{2}{*}{$\begin{array}{c}\text { Duration } \\
\text { of } \\
\text { dips } \\
\text { (min) }\end{array}$} & \multicolumn{4}{|c|}{ Concentration $\mathrm{mg} / \mathrm{L}$} & \multirow[b]{2}{*}{25} \\
\hline & & & & 0 & 2.5 & 5 & 15 & \\
\hline \multirow[t]{2}{*}{ A-39909 } & $\begin{array}{l}\text { Green } \\
\text { Green } \\
\text { Eyed } \\
\text { Eyed }\end{array}$ & $\begin{array}{l}6 \\
6 \\
5 \\
5\end{array}$ & $\begin{array}{c}15 \\
60 \\
15 \\
60\end{array}$ & $\begin{array}{l}76 \\
76 \\
82 \\
86\end{array}$ & $\begin{array}{l}5830 \\
90 \\
94\end{array}$ & $\begin{array}{c}0 \\
84 \\
0\end{array}$ & $\begin{array}{l}0 \\
8 \\
0\end{array}$ & $\begin{array}{l}0 \\
0 \\
0 \\
0\end{array}$ \\
\hline & & & & $\bar{l}$ & 2 & 4 & 12 & 20 \\
\hline \multirow[t]{2}{*}{ A-73336 } & $\begin{array}{l}\text { Green } \\
\text { Green } \\
\text { Eyed } \\
\text { Eyed }\end{array}$ & $\begin{array}{l}6 \\
6 \\
6 \\
6\end{array}$ & $\begin{array}{l}15 \\
60 \\
15 \\
60\end{array}$ & $\begin{array}{c}78 \\
84 \\
100 \\
96\end{array}$ & $\begin{array}{l}84 \\
82 \\
96 \\
96\end{array}$ & $\begin{array}{l}92 \\
84 \\
94 \\
98\end{array}$ & $\begin{array}{l}90 \\
98 \\
98 \\
96\end{array}$ & $\begin{array}{c}86 \\
84 \\
98 \\
100\end{array}$ \\
\hline & & & & $\overline{0}$ & 1 & 2 & 6 & 10 \\
\hline \multirow[t]{2}{*}{ Dichlorophen } & $\begin{array}{l}\text { Green } \\
\text { Green } \\
\text { Eyed } \\
\text { Eyed }\end{array}$ & $\begin{array}{l}6 \\
6 \\
4 \\
4\end{array}$ & $\begin{array}{l}15 \\
60 \\
15 \\
60\end{array}$ & $\begin{array}{c}68 \\
80 \\
100 \\
96\end{array}$ & $\begin{array}{l}6268 \\
96 \\
96\end{array}$ & $\begin{array}{l}6276 \\
92 \\
98\end{array}$ & $\begin{array}{l}4458 \\
96 \\
92\end{array}$ & $\begin{array}{c}624 \\
100 \\
86\end{array}$ \\
\hline & & & & $\underline{0}$ & 50 & 100 & 300 & 500 \\
\hline \multirow[t]{2}{*}{ Diquat } & $\begin{array}{l}\text { Green } \\
\text { Green } \\
\text { Eyed } \\
\text { Eyed }\end{array}$ & $\begin{array}{l}6 \\
6 \\
6 \\
6\end{array}$ & $\begin{array}{l}15 \\
60 \\
15 \\
60\end{array}$ & $\begin{array}{l}86 \\
88 \\
92 \\
94\end{array}$ & $\begin{array}{l}82 \\
88 \\
98 \\
92\end{array}$ & $\begin{array}{l}88 \\
86 \\
96 \\
94\end{array}$ & $\begin{array}{l}86 \\
94 \\
90 \\
96\end{array}$ & $\begin{array}{l}90 \\
90 \\
92 \\
94\end{array}$ \\
\hline & & & & $\underline{0}$ & 100 & 250 & 750 & 1,250 \\
\hline Formalin & $\begin{array}{l}\text { Green } \\
\text { Green } \\
\text { Eyed } \\
\text { Eyed }\end{array}$ & $\begin{array}{l}6 \\
6 \\
3 \\
3\end{array}$ & $\begin{array}{l}15 \\
60 \\
15 \\
60\end{array}$ & $\begin{array}{l}80 \\
86 \\
74\end{array}$ & $\begin{array}{l}58 \\
86 \\
74\end{array}$ & $\begin{array}{l}80 \\
80 \\
72\end{array}$ & $\begin{array}{l}80 \\
80 \\
36\end{array}$ & $\begin{array}{l}64 \\
82 \\
64 \\
60\end{array}$ \\
\hline
\end{tabular}


Appendix 7. Continued.

\begin{tabular}{|c|c|c|c|c|c|c|c|c|}
\hline \multirow[b]{2}{*}{ Chemical } & \multirow{2}{*}{$\begin{array}{l}\text { Egg } \\
\text { stage }\end{array}$} & \multirow{2}{*}{$\begin{array}{c}\text { Number } \\
\text { of } \\
\text { dips }\end{array}$} & \multirow{2}{*}{$\begin{array}{c}\text { Duration } \\
\text { of } \\
\text { dips } \\
\text { (min) }\end{array}$} & \multicolumn{4}{|c|}{ Concentration $\mathrm{mg} / \mathrm{L}$} & \multirow[b]{2}{*}{50} \\
\hline & & & & 0 & 5 & 10 & 30 & \\
\hline \multirow[t]{2}{*}{ Herbisan } & $\begin{array}{l}\text { Green } \\
\text { Green } \\
\text { Eyed } \\
\text { Eyed }\end{array}$ & $\begin{array}{l}6 \\
6 \\
3 \\
3\end{array}$ & $\begin{array}{l}15 \\
60 \\
15 \\
60\end{array}$ & $\begin{array}{l}26 \\
46 \\
42 \\
36\end{array}$ & $\begin{array}{l}22 \\
14 \\
64 \\
44\end{array}$ & $\begin{array}{l}58 \\
36 \\
54 \\
58\end{array}$ & $\begin{array}{c}56 \\
28 \\
70 \\
46\end{array}$ & $\begin{array}{c}34 \\
0 \\
52 \\
38\end{array}$ \\
\hline & & & & $\bar{E}$ & 25 & 50 & 150 & 250 \\
\hline \multirow[t]{2}{*}{$\mathrm{KMnO}_{4}$} & $\begin{array}{l}\text { Green } \\
\text { Green } \\
\text { Eyed } \\
\text { Eyed }\end{array}$ & $\begin{array}{l}6 \\
6 \\
3 \\
3\end{array}$ & $\begin{array}{l}15 \\
60 \\
15 \\
60\end{array}$ & $\begin{array}{l}80 \\
80 \\
62 \\
60\end{array}$ & $\begin{array}{l}78 \\
70 \\
62 \\
54\end{array}$ & $\begin{array}{l}66 \\
88 \\
80 \\
58\end{array}$ & $\begin{array}{l}70 \\
54 \\
86 \\
62\end{array}$ & $\begin{array}{c}64 \\
10 \\
68 \\
8\end{array}$ \\
\hline & & & & $\overline{0}$ & 2.5 & 5 & 15 & 25 \\
\hline \multirow[t]{2}{*}{ Malachite green } & $\begin{array}{l}\text { Green } \\
\text { Green } \\
\text { Eyed } \\
\text { Eyed }\end{array}$ & $\begin{array}{l}6 \\
6 \\
5 \\
5\end{array}$ & $\begin{array}{l}15 \\
60 \\
15 \\
60\end{array}$ & $\begin{array}{l}70 \\
68 \\
86 \\
86\end{array}$ & $\begin{array}{l}76 \\
60 \\
96 \\
94\end{array}$ & $\begin{array}{l}72 \\
74 \\
86 \\
92\end{array}$ & $\begin{array}{c}78 \\
76 \\
86 \\
90\end{array}$ & $\begin{array}{c}80 \\
0 \\
90 \\
54\end{array}$ \\
\hline & & & & $\overline{0}$ & 25 & 50 & 150 & 250 \\
\hline Quinolinol SO4 & $\begin{array}{l}\text { Green } \\
\text { Green } \\
\text { Eyed } \\
\text { Eyed }\end{array}$ & $\begin{array}{l}6 \\
6 \\
4 \\
4\end{array}$ & $\begin{array}{l}15 \\
60 \\
15 \\
60\end{array}$ & $\begin{array}{l}58 \\
74 \\
98 \\
94\end{array}$ & $\begin{array}{c}50 \\
6 \\
92 \\
94\end{array}$ & $\begin{array}{c}20 \\
0 \\
96 \\
94\end{array}$ & $\begin{array}{c}12 \\
0 \\
96 \\
92\end{array}$ & $\begin{array}{l}6 \\
0 \\
94 \\
64\end{array}$ \\
\hline
\end{tabular}

